\title{
Effect of climate and air pollution on radial growth of mixed forests: Abies alba Mill. vs. Picea abies (L.) Karst.
}

\author{
Petr Mikulenka ${ }^{1}$, Anna Prokůpková ${ }^{2}, Z_{\text {deněk Vacek }}^{2 *}$, Stanislav Vacek ${ }^{2}$, \\ Daniel Bulušek ${ }^{2}$, Jaroslav Simon ${ }^{1}$, Václav Šimůnek ${ }^{2}$, Vojtěch Hájek ${ }^{2}$ \\ ${ }^{1}$ Mendel University Brno, Faculty of Forestry and Wood Technology, Zemědělská 1/1665, CZ - 613 00 Brno, Czech Republic \\ ${ }^{2}$ Czech University of Life Sciences Prague, Faculty of Forestry and Wood Sciences, Kamýcká 129, \\ CZ-165 21 Prague 6 - Suchdol, Czech Republic
}

\begin{abstract}
Norway spruce (Picea abies [L.] Karst.) and silver fir (Abies alba Mill.) are main tree species of Central Europe that are currently highly vulnerable in times of global climate change. The research deals with the effect of climate and air pollution on radial growth of silver fir and Norway spruce in mixed age-varied (56-146 years) forests in the Jeseníky Protected Landscape Area, the Czech Republic. The objectives were to evaluate biodiversity, structure and production, specifically interaction of radial growth of fir and spruce to air pollution $\left(\mathrm{SO}_{2}, \mathrm{NO}_{\mathrm{x}}\right.$, tropospheric ozone) and climatic factors (precipitation, air temperature). Concentration of $\mathrm{SO}_{2}$ and $\mathrm{NO}_{x}$ had negative effect on radial growth of fir, while radial growth of spruce was more negatively influenced by tropospheric ozone. Fir showed higher variability in radial growth and was more sensitive to climatic factors compared to spruce. On the other hand, fir was relatively adaptable tree species that regenerated very well when the pressure of stress factors subsided (air pollution load, Caucasian bark beetle, frost damage). Low temperature was a limiting factor of radial growth in the study mountainous area, especially for fir. Fir was significantly sensitive to late frost, respectively, spruce to winter desiccation and spring droughts with synergism of air pollution load. Generally, older forest stands were more negatively influenced by air pollution load and climatic extremes compared to young trees.
\end{abstract}

Key words: silver fir; Norway spruce; tree-ring dating; stand structure; biodiversity; Central Europe

Editor: Bohdan Konôpka

\section{Introduction}

Silver fir (Abies alba Mill.) and Norway spruce (Picea abies [L.] Karst.) are the most productive of native European coniferous tree species (Korpel' et al. 1982). Silver fir is a tree species currently growing in Central and Southern Europe (Korpel' et al. 1982). Its range is relatively small, rather local, more or less coinciding with the distribution of mountain massifs and zones. Fir is predominantly a mountain species that, in the northern part of its area, descends to the hills or, marginally, lowlands (Hejný \& Slavík 1997). In warm climate areas it moves to higher altitudes (Musil \& Hamerník 2007). It is a species of oceanic climate with mild winters and with demands for sufficient moisture during the year (Bernadzki 2008). Silver fir suffers from strong winter frosts. Long-lasting low temperatures result in the formation of false heart (Úradníček et al. 2001). In the Czech Republic, fir concentrates in lower mountain areas. Its optimum is on gleyed and waterlogged soils at 500-900 m a.s.l. (Hejný \& Slavík 1997). Particular attention has been paid to the importance of fir in silviculture and to the consequences of its decreasing numbers in Europe since the 16th century (Cramer 1984; Larsen 1986). In the course of the last century, the reduction in numbers continued in many places (Gömöry et al. 2004) and today, both natural and anthropogenic stresses often contribute to the mortality of fir individuals (Bošela et al. 2014). In spite of that, fir and fir-mixed forests make up an important part of the central and south-eastern European landscape (EEA 2006; Bošel'a et al. 2018). On the other hand, Norway spruce has a continuous distribution in Northern Europe and islet in the mountains of Central and Southern Europe (Auders \& Spicer 2012; Farjon \& Filer 2013). In the Czech Republic, spruce occurs in the Hercynian-Carpathian region, where it grows in almost all the mountains at 700-1350 m a.s.l. (Úradníček et al. 2009). Spruce grows predominantly on poor soils of podzol and cambisol (Binkley \& Fisher 2013), where, how- 
ever, nitrogen deposition has increased forest growth in recent decades (Viet et al. 2013; Meunier et al., 2016). Spruce is very sensitive to air pollution (especially $\mathrm{SO}_{2}$ ) and droughts (Godek et al. 2015; Vacek et al. 2017, 2019). Significant disturbances in spruce stands are also caused by windstorms and bark beetle outbreaks (Čada et al. 2013; Vacek et al. 2015), especially in the context of the advancing global climate change (Hanewinkel et al. 2013).

Global climate change puts pressure on forest ecosystems (Bonan 2008; Usbeck et al. 2010; Čater \& Diaci 2017), with tree growth most affected by rising temperatures and drought (Frank et al. 2015; Hartmann et al. 2015). In general, these factors make trees more vulnerable to forest insects and pathogens (Choat et al. 2012; Anderegg et al. 2013). Consequently, a number of studies supply evidence that climatic factors also significantly affect the growth of silver fir (Gentilesca \& Todaro 2008; Koprowski 2013). In many areas, withering of firs is directly ascribed to climate change (Hanewinkel et al. 2013; Boettger et al. 2014; Konôpková et al. 2018). Accordingly, some authors suggest that fir can achieve greater productivity in mixed stands (Toïgo et al. 2015) and also that fir growth sensitivity to summer droughts is lower in mixed stands (Metz et al. 2016; Vitali et al. 2017).

In relation to climate variability, changes in the radial growth of trees and in the sequence of phenological features and their ecological species amplitude occur, whereas these changes are affecting the dynamics of the communities (Rita et al. 2014). Climate change, however, also indirectly contributes to more frequent dry seasons that are consistent with a potential 4-27\% reduction in precipitation in Europe (Ripullone et al. 2009), primarily in summer (Gao \& Giorgi 2008). In particular, warm summers and repeated drought significantly affect the health of fir and spruce (Büntgen et al. 2014; Gazol et al. 2015; Konôpková et al. 2018). The largest decline in fir growth has been recorded in the southern part of its area (Battipaglia et al. 2009; Cailleret \& Davi 2010). Hand in hand with the anticipated increase in climatic extremes (Coumou \& Rahmstorf 2012; Kogan et al. 2013) species diversity of forest ecosystems is expected to alter in many places (McDowell \& Allen 2015). This is in line with the fact that climate warming leads to shifts in species areas in response to a change in their climate optimum, with major impacts at the margins of the species areas (Davis et al. 2005; Lenoir et al. 2009; Hernández et al. 2019). From this point of view, fir is supposed to be one of the species that will replace spruce in many places because fir is more resistant to drought than spruce (Vitali et al. 2018).

Changing climate conditions will, in the future, call for emphasis on responsible, close-to-nature management based on detailed knowledge of species-specific growth responses, climate change-induced stimuli (Bolte et al. 2009; Elliott et al. 2015). Growth responses should then be investigated through annual ring increments of individuals, as annual tree-rings provide detailed retrospective information on tree growth under previous conditions of ecosystem environments (Altman et al. 2017; Sohar et al. 2017) and reliably reflect the link between growth, climatic and extreme climatic phenomena (Gazol et al. 2016; Bhuyan et al. 2017). The specific environmental conditions are usually reflected in the annual rings' width (Koprowski 2013). Some factors, such as frost or summer drought, may have an immediate effect on the ring width, while other factors such as winter drying may affect the rings with delay because growth tissues are relatively calm during winter months (Putalová et al. 2019). The effect of different environmental factors therefore causes different annual ring widths and structures that systematically alter the tree's growth dynamics (Fritts 1976; Cukor et al. 2019a, b).

In addition to climate, air pollution also has a significant impact on radial growth (Elling et al. 2009; Diaci 2011; Boettger et al. 2014; Bošela et al. 2014), as fir was considered one of the species most sensitive to air pollution (Wentzel 1980; Ulrich 1981). A strong air pollutant load, in particular, decreases the ring width significantly (Sander \& Eckstein 2001; Wilczyński 2006). However, other environmental stimuli, especially insect pests, fungal pathogens etc., also influence the variability of the ring width (Schweingruber 1996). A decline of the fir during the period of air pollution ecological disasters was often associated with the damage of fir stands caused by the Caucasian fir gall aphid (Dreyfusia nordmannianae) and the balsam woolly aphid (Dreyfusia piceae) (Mrkva 1994). Pathogenic infections also contributed to the deterioration of fir health (Brill et al. 1981; Blaschke 1982). These environmental stimuli usually manifest and pass too quickly to be a reliable indicator of forest ecosystem degradation (Godek et al. 2015). However, temporal weather anomalies within growth trends can be separated, as they are similar in all stands of the same species in the area, whether air-polluted or not; it is similar in the case of biotic pests (Ferretti et al. 2002; Sensuła et al. 2015). In recent years, increased regeneration and recovery of fir growth trend has been observed in a number of places where pollution has been reduced (Elling et al. 2009; Hauck et al. 2012).

This paper evaluates the effect of climate and air pollution on the radial growth of fir and spruce mixed age-varied forest stands cultivated by close-to-nature methods in the Jeseníky Mts. The objectives were 1) to determine structure, biodiversity and production parameters of fir-spruce mixed forest stands, 2) to compare the dynamics of radial growth of fir and spruce and their differences, 3) to describe the effect of air pollution load $\left(\mathrm{SO}_{2}, \mathrm{NO}_{\mathrm{X}}\right.$, tropospheric ozone), climatic factors (temperature, precipitation) and pathogenic infections on growth of both the study tree species and 4) to estimate the relationship between climate, air pollution and radial growth of fir and spruce. 


\section{Material and methods}

\subsection{Study area}

The area of interest is located in the Jeseníky Protected Landscape Area, in the east part of the Czech Republic. The study site belongs to the gene reserve of GZ 160-3 Hofwald silver fir and is located at the foothills of the Hrubý Jeseník mountain range on 136.4 ha at an altitude of 625-725 $\mathrm{m}$ a.s.l. The area serves for protection and reproduction of gene diversity of an important population of silver fir. The silver fir stands are richly structured, belonging to special-purpose forests and managed in the selection and shelterwood system. The annual temperature of the locality is $6.4{ }^{\circ} \mathrm{C}$, and the annual precipitation varies around $705 \mathrm{~mm}$. The vegetation period lasts 130 days. The geological base consists mainly of phyllites, partially quartzites and sediments. Mesotrophic cambisols are the predominant soil type, with sporadic pseudogleys and gleys.

Tree species composition include $40 \%$ silver fir and $20 \%$ Norway spruce. European beech (Fagus sylvatica L.), sycamore maple (Acer pseudoplatanus L.), European white birch (Betula pendula Roth.) and European larch (Larix decidua Mill.) are admixed, with black alder (Alnus glutinosa [L.] Gaertn.) on soils affected by water. The communities belong to the association Luzulo-Abietetum albae Oberdorfer 1957. Localization of permanent research plots (PRP) is shown in Fig. 1 and a summary of the PRP basic data is given in Table 1 .

\subsection{Data collection}

Field-Map technology (IFER-Monitoring and Mapping Solutions Ltd.) was used to determine the structure of the tree layer of mixed forest stands on five PRP of 50 $\times 50 \mathrm{~m}(0.25 \mathrm{ha})$ in 2018 . The positions of all trees with diameter at breast height $(\mathrm{DBH}) \geq 7 \mathrm{~cm}$ were localized. The height of the live crown base and the crown diameter were also measured in the tree layer, at least in 4 directions perpendicular to each other. Diameters of the tree layer were measured by a Mantax Blue metal calliper (Haglöf, Sweden) with an accuracy of $1 \mathrm{~mm}$ and heights

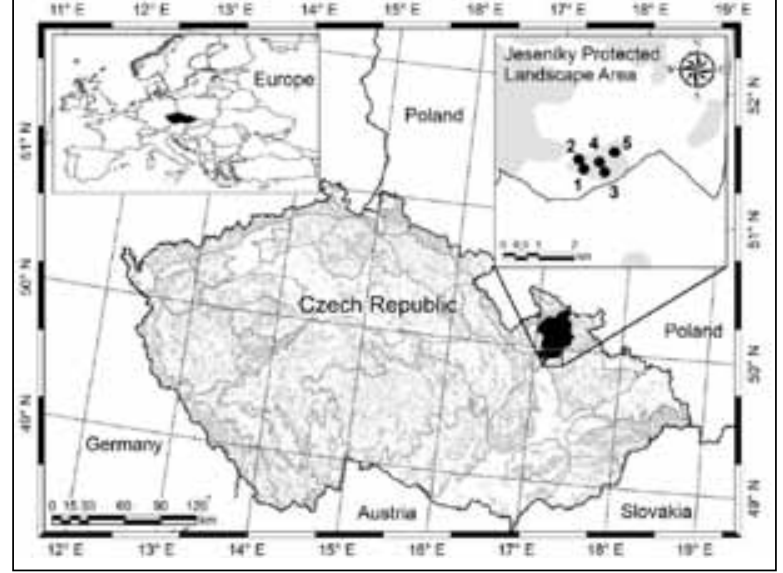

Fig. 1. Localization of mixed stands of silver fir and Norway spruce on permanent research plots Janovice 1-5 in the Jeseníky Protected Landscape Area; grey colour indicates forest cover.

were measured using a Vertex laser hypsometer (Haglöf, Sweden) with an accuracy of $0.1 \mathrm{~m}$.

Data for radial growth analysis was obtained by taking cores at a height of $1.3 \mathrm{~m}$ by a Pressler borer (Mora, Sweden) from 20 live dominant and co-dominant fir and spruce trees. The core samples were randomly (RNG function in Excel) taken from trees in upslope/downslope direction in spring 2019. Annual ring widths were measured with an accuracy of $0.01 \mathrm{~mm}$ by an Olympus binocular microscope on the LINTAB measuring table and recorded with TsapWin software (Rinntech).

\subsection{Data analysis}

The basic structure, diversity and production characteristics of the tree layer were evaluated by the SIBYLA 5.1. forest growth simulator (Fabrika \& Durský 2005). The stand volume was calculated according to Petráš \& Pajtík (1991). The relative stand density index (SDI; Reineke 1933), the crown closure (CC; Crookston \& Stage 1999) and the crown projection area (CPA) were observed for each plot. The maximum SDI value was derived from the model of the yield tables (Halaj et al.

Table 1. Overview of the basic site and stand characteristics of the permanent research plots in 2018 according to Forest Management Plan.

\begin{tabular}{|c|c|c|c|c|c|c|c|c|c|c|}
\hline PRP & GPS & $\begin{array}{l}\text { Altitude } \\
{[\mathrm{m}]}\end{array}$ & Exposition & $\begin{array}{l}\text { Slope } \\
{\left[{ }^{\circ}\right]}\end{array}$ & $\begin{array}{c}\text { Forest site } \\
\text { type }\end{array}$ & Geology & Soils & $\begin{array}{c}\text { Tree species, proportion } \\
{[\%]}\end{array}$ & $\begin{array}{l}\text { Age } \\
{[y]}\end{array}$ & $\begin{array}{l}\text { Stand volume } \\
{\left[\mathrm{m}^{3} \mathrm{ha}^{-1}\right]}\end{array}$ \\
\hline 1 & $\begin{array}{l}49^{\circ} 56.638^{\prime} \mathrm{N} \\
17^{\circ} 13.515^{\prime} \mathrm{E}\end{array}$ & 695 & SE & 7 & $5 \mathrm{~K}$ & phyllite & cambisol & AA 20, PA 50, LD 25, FS 5 & 146 & 639 \\
\hline 2 & $\begin{array}{l}49^{\circ} 56.632^{\prime} \mathrm{N} \\
17^{\circ} 13.408^{\prime} \mathrm{E}\end{array}$ & 710 & $\mathrm{E}$ & 3 & $5 \mathrm{~K}$ & quartzite & cambisol & AA 15, PA 60, LD 24, FS 1 & 139 & 605 \\
\hline 3 & $\begin{array}{l}49^{\circ} 56.573^{\prime} \mathrm{N} \\
17^{\circ} 13.817^{\prime} \mathrm{E}\end{array}$ & 660 & SE & 3 & 50 & sediment & gleysol & AA45, PA 50, AG 5 & 56 & 387 \\
\hline 4 & $\begin{array}{l}49^{\circ} 56.604^{\prime} \mathrm{N} \\
17^{\circ} 13.785^{\prime} \mathrm{E}\end{array}$ & 670 & SE & 3 & 50 & sediment & gleysol & AA 30, PA 65, AG 5 & 60 & 398 \\
\hline 5 & $\begin{array}{l}49^{\circ} 56.701^{\prime} \mathrm{N} \\
17^{\circ} 13.930^{\prime} \mathrm{E}\end{array}$ & 675 & SE & 4 & $5 \mathrm{~K}$ & sediment & cambisol & AA 40, PA 60 & 85 & 501 \\
\hline
\end{tabular}

Notes: forest site type: 50 - Fageto-Abietum variohumidum mesotrophicum, 5K - Abieto-Fagetum acidophilum; tree species: AA - silver fir (Abies alba Mill.) PA - Norway spruce (Picea abies [L.] Karst.), LD - European larch (Larix decidua Mill.) FS - European beech (Fagus sylvatica L.), AG - black alder (Alnus glutinosa [L.] Gaertn.). 
1987). Periodic annual increment (PAI) was derived for a period of 5 years. Diversity was evaluated by species richness (Margalef 1958), species heterogeneity (Shannon 1948), species evenness (Pielou 1975), Arten-profile index (Pretzsch 2006), diameter and height differentiation (Füldner 1995), crown differentiation and total stand diversity (Jaehne \& Dohrenbusch 1997; Table 2).

In order to date the core samples (16-20 analysed samples per tree species on each PRP) and eliminate the errors associated with an occurrence of missing treerings, each incremental series was cross-dated using the PAST4 statistical tests (Knibbe 2007) and subsequently subjected to visual inspection according to Yamaguchi (1991). If a missing ring was found, a ring of $0.01 \mathrm{~mm}$ width was inserted in its place. A 100-year spline in PRP 1 and 2, 50-year spline in PRP 3 and 4, and 70-year spline in PRP 5 were used to eliminate the age trend. Detrending was made in $R$, in the Dplr package. The main dendrochronological character indices were calculated, as described by methodology according to Bunn \& Mikko (2018), focusing on characterising each plot and tree species separately. The expressed population signal (EPS) was calculated for detrended data sets that indicates the reliability of a chronology as a fraction of the join variance of a theoretically infinite tree population, signal to noise ratio (SNR) that evaluates the signal strength of the chronology and R-bar inter-series correlation (Fritts 1976).

The analysis of negative pointer years characterizing extreme low radial growth was done according to Schweingruber (1996). For each tree the pointer year was tested as an extremely narrow tree-ring that does not reach $40 \%$ of the increment average from the four preceding years. The occurrence of the negative year was proved if such a strong reduction in increment occurred at least in $20 \%$ of trees on the PRP.

Data from air pollution monitoring stations and meteorological stations were used to derive air pollutant and climatic factors. An analysis of air pollution situation by $\mathrm{SO}_{2}, \mathrm{NO}_{\mathrm{x}}$ and the tropospheric ozone mean and maximum concentrations in the growing season was performed using available data from the Košetice station (1993-2017; 532 m a.s.l.; GPS 49.5735N 15.0803E). Tropospheric ozone concentration for forest was characterized by exposure index AOT40F (Werner \& Spranger 1996). Climatic factors (air temperature and precipitation) conditions were evaluated on the basis of data from the Světlá Hora meteorological station covering the years (1970-2018; 628 m a.s.l.; GPS 50.9448N, 17.2295E).
The development of air temperature and precipitation conditions was studied on the basis of a mean annual air temperature, air temperature in (non-) growing season, air temperature in individual months, annual sum of precipitation, sum of precipitation in (non-) growing season and sum of precipitation in individual months.

The standardized (detrended) tree-ring index series from the PRP were correlated by the Pearson correlation coefficient with the climate data (precipitation, air temperatures) and air pollution data $\left(\mathrm{SO}_{2}, \mathrm{NO}_{\mathrm{X}}\right.$ and tropospheric ozone concentrations) in the Statistica 12 (StatSoft, Tulsa). The DendroClim software (Biondi \& Waikul 2004) was used to model radial growth depending on climate monthly characteristics. Unconstrained principal component analysis (PCA) in Canoco 5 (Šmilauer \& Lepš 2014) was used to analyse relationships between growth of fir and spruce on the PRPs, climatic factors and air pollution data in 1993-2017. Data were log-transformed, centred and standardized before the analysis.

\section{Results}

\subsection{Structure and biodiversity of the stands}

The number of live trees ranged between $336-$ 816 trees ha ${ }^{-1}$ with the stand density index of $0.62-0.88$ in 2018 (Table 3). The mean basal area was in range of $43.4-53.3 \mathrm{~m}^{2} \mathrm{ha}^{-1}$. The stand volume ranged from $486 \mathrm{~m}^{3} \mathrm{ha}^{-1}$ (PRP 3) to $594 \mathrm{~m}^{3} \mathrm{ha}^{-1}$ (PRP 5). Fir had the largest stand volume (74.2 and 54.6\%) on two PRP ( 3 and 4), and spruce (65.9, 60.2 and 68.0\%) on three PRP (1, 2 and 5). European larch occurred only on two PRP and its share was marginal (2.2 and $4.3 \%$ ). The periodic annual increment was 7.7-10.8 $\mathrm{m}^{3} \mathrm{ha}^{-1} \mathrm{y}^{-1}$ and the mean annual increment varied between 8.1-9.9 $\mathrm{m}^{3} \mathrm{ha}^{-1} \mathrm{y}^{-1}$.

In terms of species diversity, species richness was low (D0.157-0.298), species heterogeneity ranged from low to medium $\left(H^{\prime} 0.256-0.354\right)$ and species evenness shows moderate to very high species diversity $(E 0.588-0.968$; Table 4). The vertical structure was relatively variable ( $A$ $0.428-0.675$ ), ranging from moderately diversified (PRP $1,2,4,5)$, consisting of two storeys, up to a substantially diversified spatial structure (PRP 3) which consists of 3 storeys. Füldner's index of height $\left(T M_{h} 0.132-0.532\right)$ and diameter $\left(T M_{d} 0.252-0.580\right)$ differentiation points to stands with mostly low (PRP 1, 3, 4, 5) to medium (PRP 2) structural differentiation. In terms of total stand

Table 2. Overview of indices describing the stand diversity and their common interpretation.

\begin{tabular}{|c|c|c|c|c|}
\hline Criterion & Quantifiers & Label & Reference & Evaluation \\
\hline \multirow[t]{3}{*}{ Species diversity } & Richness & D (Mai) & Margalef (1958) & minimum $\mathrm{D}=0$, higher $\mathrm{D}=$ higher values \\
\hline & Heterogeneity & $\mathrm{H}^{\prime}(\mathrm{Si})$ & Shannon (1948) & minimum $\mathrm{H}^{\prime}=0$, higher $\mathrm{H}^{\prime}=$ higher values \\
\hline & Evenness & $\mathrm{E}(\mathrm{Pii})$ & Pielou (1975) & range $0-1 ;$ minimum $E=0$, maximum $E=1$ \\
\hline Vertical diversity & Arten-profile index & A(Pri) & Pretzsch (2006) & range $0-1$; balanced vertical structure $A<0.3$; selection forest $A>0.9$ \\
\hline Structure differentiation & $\begin{array}{l}\text { Diameter dif. } \\
\text { Height dif. }\end{array}$ & $\begin{array}{l}\mathrm{TM}_{\mathrm{d}}(\mathrm{Fi}) \\
\mathrm{TM}_{\text {(Fi) }}\end{array}$ & Füldner (1995) & range $0-1$; low $\mathrm{TM}<0.3$; very high differentiation $\mathrm{TM}>0.7$ \\
\hline & Crown dif. & $\mathrm{K}(\mathrm{J} \& \mathrm{Di})$ & Jaehne \& Dohrenbusch (1997) & low $\mathrm{K}<1$; very high differentiation $\mathrm{K}>3$ \\
\hline Complex diversity & Stand diversity & B (J\&Di) & Jaehne \& Dohrenbusch (1997) & $\begin{array}{l}\text { monotonous structure } B<4 \text {; uneven structure } B=6-8 \text {; very diverse } \\
\text { structure } B>9\end{array}$ \\
\hline
\end{tabular}


Table 3. Structural and production characteristics on permanent research plots 1-5 in 2018.

\begin{tabular}{|c|c|c|c|c|c|c|c|c|c|c|c|c|}
\hline PRP & $\begin{array}{l}\text { Age } \\
\text { [y] }\end{array}$ & $\begin{array}{l}\mathrm{dbh} \\
{[\mathrm{cm}]}\end{array}$ & $\begin{array}{c}\mathrm{h} \\
{[\mathrm{m}]}\end{array}$ & $\begin{array}{c}\mathrm{v} \\
{\left[\mathrm{m}^{3}\right]}\end{array}$ & $\begin{array}{c}\mathrm{N} \\
{\left[\text { trees ha }^{-1}\right]}\end{array}$ & $\begin{array}{c}\text { BA } \\
{\left[\mathrm{m}^{2} \mathrm{ha}^{-1}\right]}\end{array}$ & $\begin{array}{c}\mathrm{V} \\
{\left[\mathrm{m}^{3} \mathrm{ha}^{-1}\right]}\end{array}$ & $\begin{array}{l}\text { PAI } \\
\qquad \mathrm{m}^{3} \mathrm{ha}^{-1} \mathrm{y}^{-}\end{array}$ & $\begin{array}{l}\text { MAI } \\
\left.{ }^{-1}\right]\end{array}$ & $\begin{array}{c}\mathrm{CC} \\
{[\%]}\end{array}$ & $\begin{array}{l}\mathrm{CPA} \\
\text { [ha] }\end{array}$ & SDI \\
\hline \multicolumn{13}{|c|}{ Abies alba } \\
\hline 1 & 146 & 22.0 & 11.78 & 0.465 & 352 & 13.1 & 164 & 2.6 & 2.73 & 44.8 & 0.59 & 0.25 \\
\hline 2 & 139 & 38.8 & 23.74 & 1.563 & 144 & 16.6 & 225 & 3.5 & 3.75 & 32.4 & 0.39 & 0.26 \\
\hline 3 & 56 & 32.4 & 23.75 & 0.902 & 400 & 33.0 & 361 & 7.5 & 6.02 & 70.1 & 1.21 & 0.54 \\
\hline 4 & 60 & 27.4 & 21.20 & 0.599 & 480 & 28.3 & 288 & 7.1 & 4.80 & 78.9 & 1.55 & 0.49 \\
\hline 5 & 85 & 41.3 & 29.41 & 1.692 & 112 & 15.0 & 189 & 3.7 & 3.15 & 50.2 & 0.70 & 0.22 \\
\hline \multicolumn{13}{|c|}{ Picea abies } \\
\hline 1 & 146 & 43.6 & 30.20 & 1.901 & 192 & 28.5 & 365 & 4.1 & 6.08 & 49.3 & 0.68 & 0.38 \\
\hline 2 & 139 & 42.5 & 27.62 & 1.768 & 192 & 26.8 & 340 & 4.2 & 5.67 & 48.8 & 0.67 & 0.37 \\
\hline 3 & 56 & 30.3 & 23.24 & 0.710 & 176 & 12.7 & 125 & 1.9 & 2.08 & 39.7 & 0.51 & 0.20 \\
\hline 4 & 60 & 30.8 & 23.22 & 0.711 & 320 & 23.8 & 228 & 3.3 & 3.80 & 65.6 & 1.07 & 0.37 \\
\hline 5 & 85 & 38.5 & 27.14 & 1.330 & 304 & 35.2 & 404 & 4.1 & 6.73 & 75.8 & 1.42 & 0.50 \\
\hline \multicolumn{13}{|c|}{ All tree layer } \\
\hline$\overline{1}$ & 146 & 30.5 & 17.96 & 0.911 & 608 & 43.9 & 554 & 6.8 & 9.23 & 77.4 & 1.49 & 0.68 \\
\hline 2 & 139 & 40.7 & 25.96 & 1.680 & 336 & 43.4 & 565 & 7.7 & 9.42 & 65.4 & 1.06 & 0.62 \\
\hline 3 & 56 & 31.8 & 23.59 & 0.843 & 576 & 45.6 & 486 & 9.4 & 8.10 & 82.0 & 1.71 & 0.73 \\
\hline 4 & 60 & 28.9 & 22.08 & 0.646 & 816 & 53.3 & 527 & 10.8 & 8.78 & 93.2 & 2.69 & 0.88 \\
\hline 5 & 85 & 39.3 & 27.75 & 1.428 & 416 & 50.2 & 594 & 7.6 & 9.90 & 88.0 & 2.12 & 0.72 \\
\hline
\end{tabular}

Table 4. Biodiversity of tree layer on permanent research plots $1-5$ in 2018.

\begin{tabular}{|c|c|c|c|c|c|c|c|c|}
\hline PRP & $\begin{array}{c}\text { D } \\
\text { (Mai) }\end{array}$ & $\begin{array}{l}\mathrm{H}^{\prime} \\
(\mathrm{Si})\end{array}$ & $\begin{array}{c}\mathrm{E} \\
\text { (Pii) }\end{array}$ & $\begin{array}{c}\text { A } \\
\text { (Pri) }\end{array}$ & $\begin{array}{l}\mathrm{TM}_{\mathrm{d}} \\
\text { (Fi) }\end{array}$ & $\begin{array}{l}\mathrm{TM}_{\mathrm{h}} \\
(\mathrm{Fi})\end{array}$ & $\begin{array}{c}\mathrm{K} \\
(\mathrm{J} \& \mathrm{Di})\end{array}$ & $\begin{array}{c}\text { B } \\
(J \& D i)\end{array}$ \\
\hline 1 & 0.157 & 0.354 & 0.588 & 0.531 & 0.300 & 0.256 & 1.983 & 7.320 \\
\hline 2 & 0.298 & 0.289 & 0.960 & 0.488 & 0.580 & 0.532 & 1.720 & 5.630 \\
\hline 3 & 0.166 & 0.256 & 0.850 & 0.675 & 0.291 & 0.176 & 0.805 & 3.917 \\
\hline 4 & 0.172 & 0.342 & 0.717 & 0.551 & 0.300 & 0.183 & 0.938 & 5.236 \\
\hline 5 & 0.161 & 0.265 & 0.880 & 0.428 & 0.252 & 0.132 & 0.784 & 3.506 \\
\hline
\end{tabular}

Notes: D - species richness index, $\mathrm{H}^{\prime}$ - species heterogeneity index (entropy), $\mathrm{E}$ - species evenness index, A-Arten-profile index, $\mathrm{TM}_{\mathrm{d}}-$ diameter differentiation index, $\mathrm{TM}_{\mathrm{h}}$ - height differentiation index, $\mathrm{K}$ - crown differentiation index, $\mathrm{B}$ - total diversity index.

diversity, PRP 3 and 5 show monotonous structure $(B$ 3.506-3.917), PRP 2 and 4 even structure ( $B$ 5.2365.630) and PRP 1 shows uneven structure $(B=7.630)$. The crown differentiation ranges from fairly low (PRP $3-5)$ to moderate (PRP 1 and 2). Generally high biodiversity was on older (139-146 y) mature forest stands on PRP 1-2 compared to younger stands (56-85 y) on PRP 3-5.

\subsection{Tree-ring characteristics}

Characteristics of dendrochronology analysis are numerically described in Table 5 that shows basic indicators. Average tree-ring width was the lowest on PRP 1 in spruce $(1.63 \mathrm{~mm} \pm 0.69 \mathrm{SD})$ and on PRP 2 in fir $(1.63 \mathrm{~mm} \pm 0.98 \mathrm{SD})$ on the oldest PRP, while the highest increment was on PRP 3 in spruce $(3.84 \mathrm{~mm} \pm 1.39$ $\mathrm{SD})$. Generally, the higher radial growth was in spruce compared to fir (except PRP 1). Expression population signal value shows a high number in PRP 4 (0.944 and 0.903), but EPS was significant (significant EPS level is 0.850 ) in both tree species on all PRP except fir on PRP 2 (0.849). SNR value shows that best chronology (without noise) was in fir on PRP 3 and 4 (16.938 and 11.353). The highest SNR noise was described in fir on the oldest PRP 1 and 2 (3.078 and 5.260). First-order autocorrelation shows values ranging from 0.654 to 0.844 and R-bar from 0.241 to 0.504 .

\subsection{Dynamics of radial growth of fir and spruce}

Significant negativeyears with low radial increment were observed in older stands on PRP 1, 2 and 5 and in one case on PRP 3 (Table 6). Significant decrease in radial growth was observed especially in fir (3-5 significant years) compared to spruce (1-3 significant years). On

Table 5. Characteristics of the tree-ring chronologies of fir and spruce on permanent research plots 1-5.

\begin{tabular}{|c|c|c|c|c|c|c|c|c|}
\hline PRP & Species & No. of trees & SD & Mean [mm] & ar1 & R-bar & EPS & SNR \\
\hline \multirow{2}{*}{1} & SP & 18 & 0.69 & 1.63 & 0.762 & 0.311 & 0.879 & 7.265 \\
\hline & $\mathrm{AA}$ & 17 & 0.97 & 1.69 & 0.835 & 0.267 & 0.859 & 5.260 \\
\hline \multirow{2}{*}{2} & SP & 18 & 0.89 & 1.75 & 0.784 & 0.329 & 0.889 & 8.001 \\
\hline & AA & 16 & 0.98 & 1.63 & 0.844 & 0.241 & 0.849 & 3.078 \\
\hline \multirow{2}{*}{3} & SP & 20 & 1.39 & 3.84 & 0.723 & 0.288 & 0.854 & 5.830 \\
\hline & $\mathrm{AA}$ & 20 & 1.29 & 3.60 & 0.654 & 0.405 & 0.919 & 11.353 \\
\hline \multirow{2}{*}{4} & SP & 19 & 1.38 & 3.32 & 0.773 & 0.354 & 0.903 & 9.302 \\
\hline & $\mathrm{AA}$ & 20 & 1.17 & 2.89 & 0.731 & 0.504 & 0.944 & 16.938 \\
\hline \multirow[b]{2}{*}{5} & SP & 17 & 1.23 & 2.93 & 0.752 & 0.380 & 0.894 & 8.449 \\
\hline & $\mathrm{AA}$ & 20 & 1.31 & 2.65 & 0.814 & 0.367 & 0.899 & 8.895 \\
\hline
\end{tabular}

Notes: No. of trees - number of analyzed samples, SD - standard deviation, ar1 - first-order autocorrelation, R-bar - inter-series correlation, EPS - expression population signal, SNR - signal-tonoise ratio. 
PRP 1, 2 and 5, the radial dynamics of fir showed decrease caused by the Caucasian fir gall aphid in synergism with air pollution in 1970-1982 (Fig. 2). Significant negative years with low radial increment of fir in 1929, 1933, 1956, 1962 and 1996 were caused by cold years, when the assimilation apparatus was damaged by late frosts. In 1996, the mean coldest temperature from January to March was measured $\left(-5.3^{\circ} \mathrm{C}\right.$ in 1996 , mean $\left.-1.5^{\circ} \mathrm{C}\right)$.

Table 6. Significant negative pointer years characterizing extreme low radial growth of fir and spruce on permanent research plots $1-5$.

\begin{tabular}{lcc}
\hline Negative pointer years & Silver fir & Norway spruce \\
\hline PRP 1 & $1929,1956,1962,1996$ & 1948,1993 \\
PRP 2 & $1929,1933,1956,1972,1996$ & $1980,1993,2004$ \\
PRP 3 & - & 1965 \\
PRP 4 & - & - \\
PRP 5 & $1962,1979,1996$ & - \\
\hline
\end{tabular}

In spruce, significant negative year 1993 was characterized by the synergism of the highest max. $\mathrm{SO}_{2}$ con-

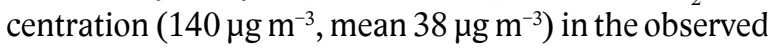
period and a lack of precipitation ( $28 \mathrm{~mm}$, mean $52 \mathrm{~mm}$ ) on the beginning of growing season (March-May). More significant winter desiccation also occurred in the early spring of 1948 and in 1992-1995. Reduced increment in spruce in 2004 was caused by low precipitation in the growing season. In the study period, several increases in radial growth were observed due to favourable climatic conditions, but also because of silviculture intervention, especially in younger forest stands. For example, on PRP 4 due to strong competition, thinning of $34 \mathrm{~m}^{3} \mathrm{ha}^{-1}$ was carried out in 2006 and the radial increment subsequently increased (Fig. 2).
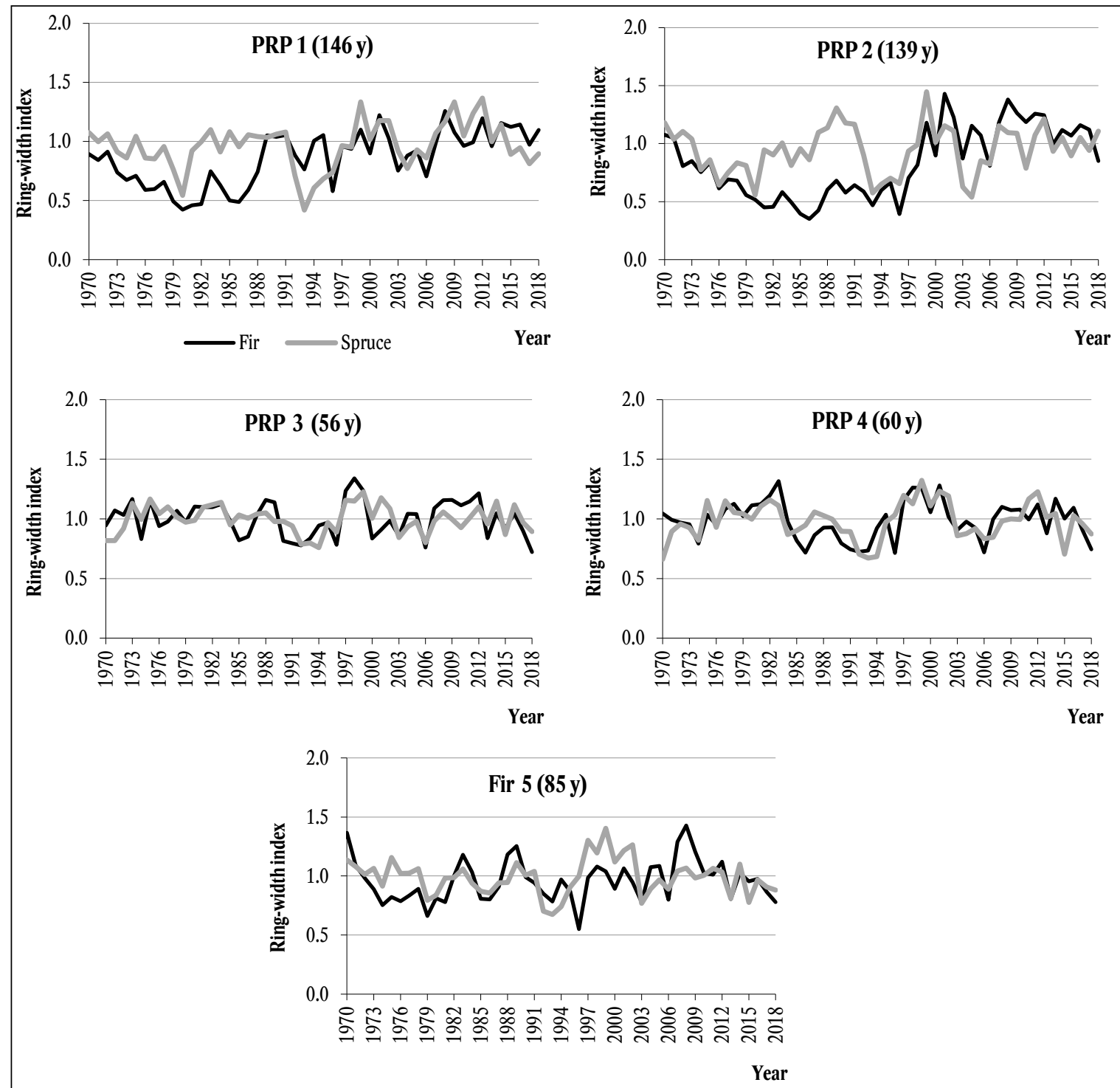

Fig. 2. Standardized mean chronology of silver fir (black line) and Norway spruce (gray line) in 1970-2018 expressed by the tree-ring index on permanent research plots 1-5 (the number of samples in 1970 - PRP 3: spruce 50\% and fir 75\%; PRP 4: spruce $58 \%$ and fir $75 \%$; PRP 1, 2 and $5100 \%$ of spruce and fir; in $1978100 \%$ of samples on PRP 1-5). 
Generally, the higher variability in radial growth was observed in fir ( \pm 0.20 SD) in 1970- 2018, while the standardized mean site chronology of spruce was relatively more balanced $( \pm 0.16 \mathrm{SD})$ with partial fluctuations (Fig. 2). Since 1993 the comparable situation in growth variability ( $\pm 0.18 \mathrm{SD}$ ) has been observed in both tree species. The variability of radial growth was increasing with age of trees, while the highest fluctuation was on PRP 1 and $2(136-146 \mathrm{y} ; \pm 0.23 \mathrm{SD})$ and the lowest on PRP 3 and 4 (56-60 y; \pm 0.14 SD).

\subsection{Effect of climatic factors on radial growth of fir and spruce}

Climatic analyses in relation to radial growth showed several significant $(\alpha=0.05 \% ; r=-0.34-0.36)$ months in 1970-2018 (Fig. 3). Radial growth of fir was more sensitive to monthly temperature and precipitation compared to spruce. To be precise, on the oldest PRP 1, fir was the most sensitive to climatic factors ( 8 significant months) from all variants (PRP and tree species). The air temperature had significant effect on radial growth of fir

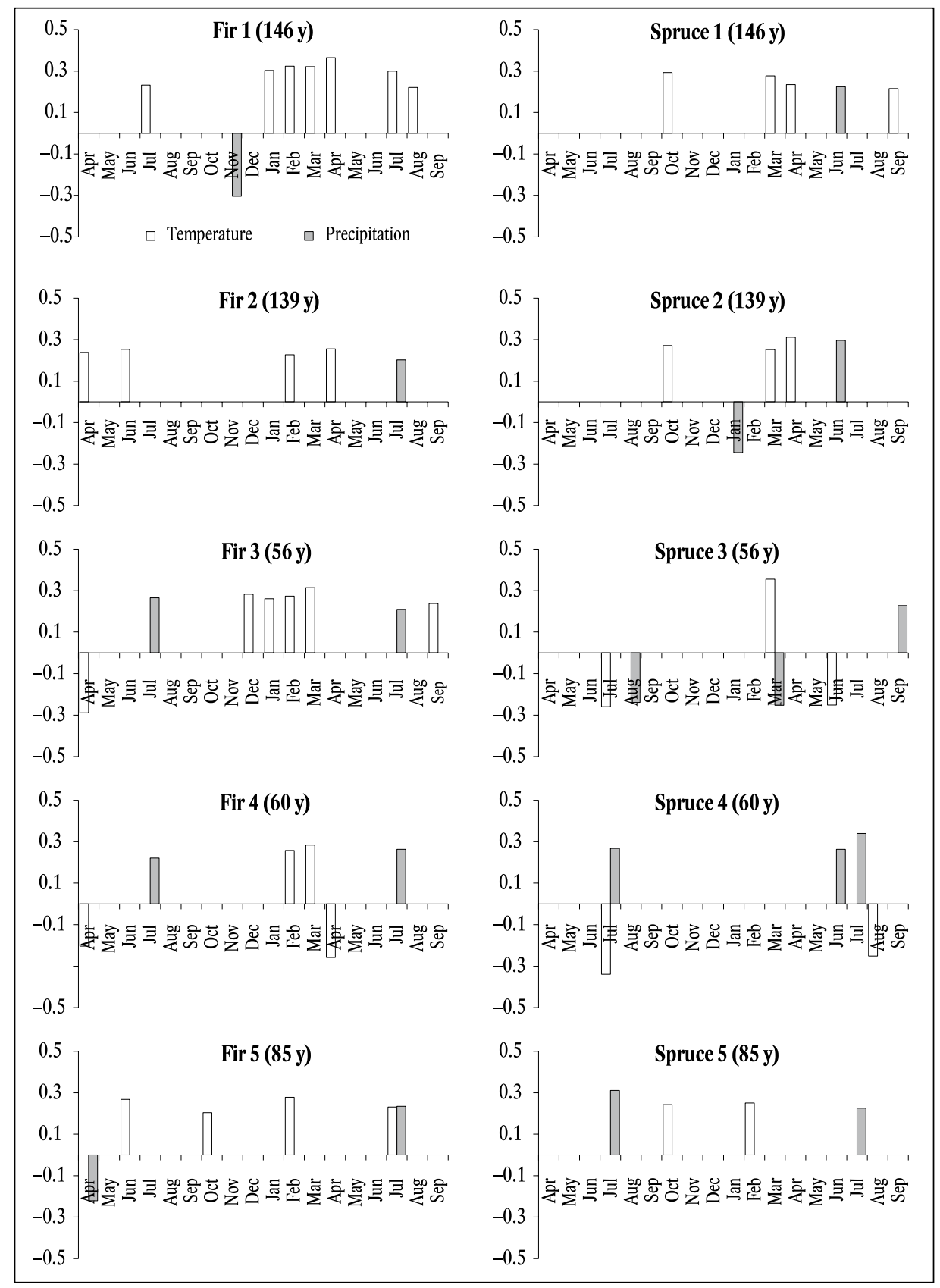

Fig. 3. Correlation coefficients of the standardized tree-ring index chronology of silver fir (left) and Norway spruce (right) with the monthly air temperature (white colour) and precipitation (grey colour) from April to December of the preceding years (capitals) and from January to September of the current year (lower case) on permanent research plots 1-5 in 1970-2018. Only correlation coefficients of statistically significant values are presented $(\alpha=0.05 \%)$. 
compared to low impact of precipitation. The effect of air temperature was prevailingly positive on all PRP, while in spruce on PRP 3 and 4 the effect of temperature was negative. July (in precipitation) together with February, March and April (in air temperature) were the most significant months in relation to climate-sensitive on radial growth of fir.

In spruce, climate sensitivity of diameter increment was similar on all PRP (4-6 significant months) compared to high variability in fir (5-8 significant months). In younger forest stands, the effect of precipitation was prevailing or equable, while radial growth of spruce in older stands was more affected by air temperature. Diameter increment of spruce was positively correlated especially with the precipitation in June and with air temperature in October of the previous year and March of the current year (Fig. 3).

\subsection{Interactions between radial growth, air pollution and climate}

Maximum and mean $\mathrm{SO}_{2}$ concentrations had significant negative effect on fir and spruce radial growth in the oldest stands on PRP 1 and 2 and in fir on PRP 5 (p $<0.05-0.001$; Table 7). The highest effect of $\mathrm{SO}_{2}$ concentration was observed in fir $(p<0.01)$ compared to spruce $(\mathrm{p}<0.05) . \mathrm{NO}_{\mathrm{X}}$ concentrations were in significant negative correlation with fir radial growth on PRP 1, 2 and $4(p<0.05-0.01)$, while no significant effect was observed in spruce. The mean AOT40F had a similarly negative effect on fir and spruce radial growth, especially on PRP 1 and 2. Conversely, maximum value of exposure index was in significant negatively correlation with spruce growth an all PRP ( $\mathrm{p}<0.05-0.01)$, while in fir it was observed only on two PRP. Generally, $\mathrm{SO}_{2}$ and $\mathrm{NO}_{\mathrm{x}}$ concentrations had higher effect on fir radial growth, while spruce diameter increment was more influenced by tropospheric ozone. The effect of air temperature on fir and spruce radial growth was significant. The highest effect on radial growth $(p<0.001)$ was exerted by mean annual air temperature of the current year, especially in fir. On the other hand, precipitation did not have any significant effect on the fir radial growth stands $(p>0.05)$ compared to two (on PRP 4 and 5) significant correlations $(\mathrm{p}<0.05)$ with a sum of precipitation in the growing season of the current year.

The results of PCA are represented in an ordination diagram in Fig. 4. The first ordination axis explains $43.3 \%$ of data variability, the first two axes together explain $59.4 \%$ and the first four axes $75.2 \%$. The x-axis illustrates the mean radial growth of fir stands along with ozone exposure index (AOT40F) and the second y-axis represents the sum of precipitation in the current year and in the growing season. $\mathrm{SO}_{2}$ and $\mathrm{NO}_{\mathrm{X}}$ concentrations (mean annual and maximum) were negatively correlated with radial growth of fir and spruce PRP 1 and 2, while ozone exposure index had prevailing negative effect on radial growth of spruce and silver fir on PRP 1 and 2. In relation to air pollution, $\mathrm{SO}_{2}$ concentrations contribute greatly to the explained variability by the first principal component. On the other hand, precipitation, in terms of climatic factors, contributes less to the explained variability compared to air temperature, especially low effect of precipitation in the non-growing season was observed. Overall, the effect of air temperature on diameter increment was more significant in fir compared to spruce. Conversely, precipitation had higher effect on radial growth in spruce, both especially in the growing season in younger forest stands.

\section{Discussion}

On the European scale, increased forest ecosystem increment has been apparent since the 1970s, having been often attributed to rising air temperatures in combination with increased nitrogen deposition and increasing atmospheric $\mathrm{CO}_{2}$ (De Vries et al. 2006; Bontemps et al. 2011). In the Czech Republic, however, the increment of stands has also been significantly limited by a number of negative factors during this period (Putalová et al. 2019;

Table 7. Correlation matrix describing interactions between radial growth of fir and spruce (on permanent research plots 1-5 and summary), precipitation and air temperature (1970-2018) and concentrations of $\mathrm{SO}_{2}, \mathrm{NO}_{\mathrm{x}}$ and AOT40F (1993-2017). Significant correlations are designated by * $(p<0.05)$ and $* *(p<0.01)$.

\begin{tabular}{|c|c|c|c|c|c|c|c|c|c|c|}
\hline RWI & $\begin{array}{c}\mathrm{SO}_{2} \\
\text { mean }\end{array}$ & $\begin{array}{l}\mathrm{SO}_{2} \\
\max \end{array}$ & $\begin{array}{l}\mathrm{NO}_{\mathrm{x}} \\
\text { mean }\end{array}$ & $\begin{array}{l}\mathrm{NO}_{\mathrm{X}} \\
\max \end{array}$ & $\begin{array}{c}\text { AOT40F } \\
\text { mean }\end{array}$ & $\begin{array}{c}\text { AOT40F } \\
\max \end{array}$ & $\begin{array}{c}\text { Temp } \\
\text { ActAnn }\end{array}$ & $\begin{array}{c}\text { Temp } \\
\text { ActVeg }\end{array}$ & $\begin{array}{c}\text { Prec } \\
\text { ActAnn }\end{array}$ & $\begin{array}{c}\text { Prec } \\
\text { ActVeg }\end{array}$ \\
\hline$\overline{\text { Fir1 }}$ & $-0.49^{*}$ & -0.51 ** & $-0.52 * *$ & -0.33 & $-0.58^{* *}$ & -0.35 & $0.61^{* *}$ & $0.43^{*}$ & -0.18 & -0.01 \\
\hline Fir2 & $-0.87 * *$ & $-0.83^{* *}$ & -0.26 & -0.51 ** & -0.57 ** & $-0.58^{* *}$ & $0.42 *$ & 0.26 & -0.14 & -0.03 \\
\hline Fir3 & -0.17 & -0.20 & 0.02 & -0.19 & -0.22 & -0.32 & 0.02 & -0.05 & 0.06 & 0.13 \\
\hline Fir4 & -0.35 & -0.39 & -0.22 & $-0.41^{*}$ & -0.39 & -0.39 & 0.14 & -0.04 & 0.16 & 0.22 \\
\hline Fir5 & -0.47 * & -0.50 * & -0.20 & -0.20 & $-0.42 *$ & -0.31 & $0.34 *$ & 0.17 & 0.01 & 0.12 \\
\hline Fir $\Phi$ & $-0.62 * *$ & $-0.63 * *$ & -0.28 & -0.41 & -0.50 * & $-0.47^{*}$ & $0.45^{* *}$ & 0.25 & -0.07 & 0.09 \\
\hline Spruce1 & $-0.65^{* *}$ & $-0.60 * *$ & -0.03 & -0.37 & $-0.56^{* *}$ & $-0.65^{* *}$ & 0.23 & 0.21 & -0.05 & 0.08 \\
\hline Spruce2 & $-0.54 * *$ & $-0.48 *$ & -0.20 & -0.18 & $-0.51 * *$ & -0.47 * & $0.40^{* *}$ & $0.35^{*}$ & -0.07 & 0.06 \\
\hline Spruce3 & -0.31 & -0.29 & -0.15 & -0.22 & $-0.45^{*}$ & $-0.56^{* *}$ & 0.04 & -0.12 & 0.15 & 0.23 \\
\hline Spruce4 & -0.21 & -0.17 & -0.04 & -0.26 & -0.34 & $-0.56^{* *}$ & -0.06 & -0.09 & 0.17 & $0.29^{*}$ \\
\hline Spruce5 & -0.17 & -0.14 & -0.07 & -0.24 & -0.26 & -0.51 ** & 0.07 & -0.08 & 0.18 & $0.34^{*}$ \\
\hline Spruce $\Phi$ & $-0.45^{*}$ & $-0.40^{*}$ & -0.09 & -0.28 & $-0.48^{*}$ & $-0.61 * *$ & 0.19 & 0.10 & 0.07 & 0.22 \\
\hline
\end{tabular}




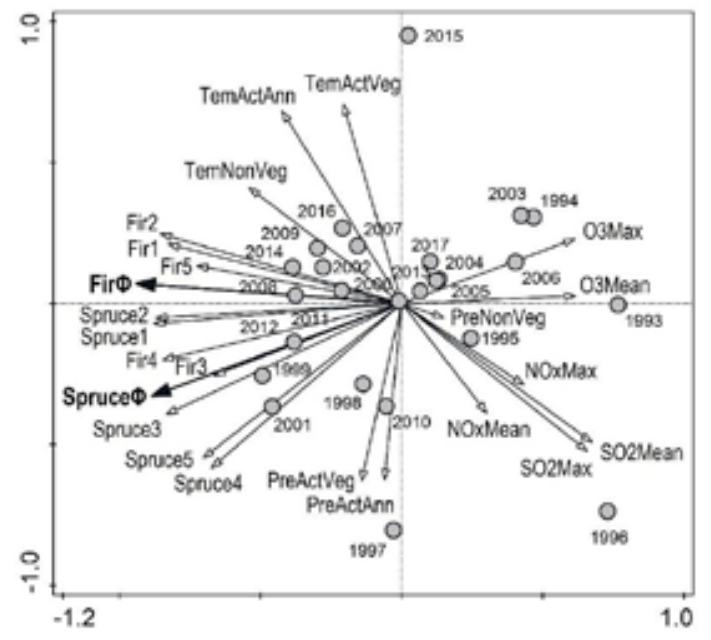

Fig. 4. Ordination diagram of PCA showing relationships between climate data (Tem - mean air temperature, Pre - sum of precipitation, Act - current year, Veg - growing season, NonVeg - nongrowing season), ozone exposure index $\mathrm{AOT} 40 \mathrm{~F}$ and $\mathrm{SO}_{2}$ and $\mathrm{NO}_{\mathrm{x}}$ concentrations (mean - mean annual concentration, max - maximum concentration) and tree-ring width for fir and spruce on permanent research plots $1-5$ and on average $(\Phi)$; codes $\bullet$ indicate years 1993-2017.

Vacek et al. 2019). Our results clearly confirm this effect of various negative factors, both biotic and abiotic, on the radial increment of fir and spruce on the studied plots. Climatic factors showed considerable variability over the studied period: the increment at the beginning of the period was influenced by cold or frost damage, while at the end of the period, the effect of higher air temperatures and lower precipitation totals was more prominent, which is, essentially, in line with the climate change. Other climate change research led to similar results (Hanewinkel et al. 2013; Konôpková et al. 2018). Specifically, fir was affected not only by the climate but also by the Caucasian fir gall aphid and air pollution in our conditions. This confirms greater variability in radial growth in fir on the study PRP compared to spruce. Although after year 1993, the fir showed significant increase and stabilization in radial growth. Overall, fir proved to be significantly more sensitive to $\mathrm{NO}_{\mathrm{x}}$ and $\mathrm{SO}_{2}$ concentrations in comparison to spruce, especially in older forest stands. On the other hand, spruce was more sensitive to the ozone exposure index. Generally, older stands were more sensitive to the air pollution load, climatic factors and changes in comparison to younger forest, in which radial growth is more influenced by tree competition and silvicultural intervention.

The mixing of tree species in forest stands also plays an important role (Vacek et al. 2019). Vitali et al. (2017) reported lower growth sensitivity to summer droughts in mixed stands. Mina et al. (2018), in turn, documented that the increment of spruce and fir trees is higher when growing together in a mixed stand rather than in monocultures. Similar results are also reported by Toïgo et al. (2015). Forrester et al. (2013) then give reasons for better increment in mixed stands compared to monocultures by more efficient use of underground resources rather than the above-ground. Also, in the case of mixed stands, a better litter ratio and the mineral nutrient cycle in general maybe a positive factor (Block 1997; Augusto et al.2002). In the case of mixing fir and spruce, the positive effects are justified by their ability to create different root systems (Forrester \& Albrecht 2014). It can thus be assumed that the variability of increment on the PRP studied in this work was reduced due to mixing. This statement can also be supported by results from monoculture stands where the variability of increment is more diverse (Putalová et al. 2019). On the other hand, the positive effect of mixing on increment strongly depends on climatic and habitat conditions (Huber et al. 2014). However, the effect of climate change may not be negative in alpine areas or at high altitudes (Bolte et al. 2010; Di Filippo et al. 2012).

Climate change effects also depend on tree species (Rötzer et al. 2017a; Vacek et al. 2018). Pretzsch et al. (2013) documented that spruce, unlike beech, reacts to drought by a more pronounced decrease in increment. However, when comparing the increment of spruce and fir, our results do not confirm such development unambiguously. On the other hand, it is necessary to admit that a number of various factors affected the studied areas and, thus, it is hard to single out and quantify solely the influence of drought on the increment. Accordingly, the effect of the air temperature and precipitation in the individual months on the increment of individual tree species is also highly differentiated. However, it is clear from the results that climate data have a significant effect on the increment, which corresponds to the results of correlation analyses of numerous other works, e.g. Dittmar et al. (2003), Friedrichs et al. (2009) or Härdtle et al. (2013). On the basis of long-term research, Vitali et al. (2018) confirm positive correlation of lower-altitudes increment with summer precipitation and negative correlation with summer air temperatures, both for spruce and for fir; this study, though, does not bring significant higher-altitude correlation neither for spruce nor for fir. In the study area (660-710 $\mathrm{m}$ a.s.l.) air temperature had prevailingly positive significant effect on radial growth, especially in the first quarter of the year and more in fir compared to spruce.

Relatively significant differentiation of our results can be explained both by the microhabitat conditions and the different type of root systems. Trees may also manifest different incremental responses in the context of a species-specific form of water management strategy, where isohydric species such as spruce close their stomata in dry seasons to maintain a consistent minimum water leaf potential to prevent high water losses and water balance disruption in the plant (del Río et al. 2014). However, this reaction may result in reduced photosynthetic activity and overall reduction in increment (Klein 2014; Roman et al. 2015). Also, different drought adaptation strategies vary from species to species, and can generate better main- 
tenance of osmoregulatory and hydrological functions (O'Brien et al. 2014). Moreover, the mixing of deciduous and indeciduous tree species can lead to better growth by diversifying sources from the environment, which can ultimately lead to stress reduction (Pretzsch et al. 2014). In our case, for example, spruce and fir trees can benefit from greater amounts of light and water through larch crown leakage in spring and winter, when larches do not have needles. Rötzer et al. (2017b) describe an illustrative example of such profitable relationship between spruce and beech. Last but not least, a different type of root system also contributes to increased resource efficiency in stands (Dănescu et al. 2016). Higher spring air temperatures are also favoured by the fir as they reduce late frosts to which fir is sensitive (Lebourgeois et al. 2010) and accelerate the onset of cambial activity (Gričar \& Čufar 2008; Swidrak et al. 2014). Similarly, in our study, high air temperature in February and March significantly positively influenced radial growth of fir. Moreover, June and July (the period when a great part of radial increment is produced) were confirmed as significant months in the Jeseníky Mts., such as in other mountain spruce forests (Král et al. 2015; Králíček et al. 2017). Mild winter conditions may also improve the increment (Harrington et al. 2010). Conversely, correlation between the increment of fir and precipitation at medium and higher altitudes is generally not as significant as the air temperature (Rolland et al. 1999; Carrer et al. 2010). On the study PRP, low air temperature was a significant limiting factor of radial growth of firs compared to low correlation with precipitation. Significantly higher effect of precipitation on diameter increment was observed in spruce because of higher altitude optimum for its growth.

\section{Conclusion}

The study of radial growth in mixed age-varied fir-spruce forest stands in the Jeseníky Mts. Protected Landscape Area documents higher growth variability and sensitivity to climatic factors and air pollution $\left(\mathrm{SO}_{2}\right.$ and $\mathrm{NO}_{\mathrm{X}}$ concentrations) in fir compared to spruce. A significant reduction in the radial increment of fir in the late 1970s and early 1980s was induced by air pollution in synergism with Caucasian fir gall aphid infestation, late frosts and winter desiccation. Impact of numerous negative factors is clearly seen on the increment in not only fir, but also in spruce. In spruce, it is primarily the impact of air pollution (especially max. tropospheric ozone concentrations) and drought. On the other hand, fir is a very flexible tree species that regenerates well when the stress factors impact subsides (air pollution, climatic extremes, pathogens). It is therefore a perspective stabilizing tree species, which, even in the face of global climate change, plays an important role in forest ecosystems. What matters is its ability to be an important soil improving tree species and a productive part of various mixed forest stand with sun- tolerant, semi shadow- and shadow-tolerant tree species. A support of fir in suitable habitats is further enhanced by the large-scale decline of spruce, not only in the Czech Republic but also in all Central Europe.

\section{Acknowledgments}

This study was supported by the Ministry of Agriculture of the Czech Republic (NAZVNo. QK11910292) and by the CzechUniversity of Life Sciences Prague, Faculty of Forestry and Wood Sciences (IGA No. A02/19). We are grateful to two anonymous reviewers and editor-in-chief for their constructive comments and valuable suggestions that helped improve the manuscript.

\section{References}

Altman, J., Fibich, P., Santruckova, H., Dolezal, J., Stepanek, P., Kopacek, J. et al., 2017: Environmental factors exert strong control over the climate-growth relationships of Picea abies in Central Europe. Science of the Total Environment, 609:506-516.

Anderegg, W. R., Kane, J. M., Anderegg, L. D., 2013: Consequences of widespread tree mortality triggered by drought and temperature stress. Nature Climate Change, 3:30-36.

Auders, A. G., Spicer, D. P., 2012: Royal Horticultural Society Encyclopedia of Conifers: A Comprehensive Guide to Cultivars and Species. Royal Horticultural Society, 1507 p.

Augusto, L., Ranger, J., Binkley, D., Rothe, A., 2002: Impact of several common tree species of European temperate forests on soil fertility. Annal of Forest Sciences, 59:233-253.

Battipaglia, G., M. Saurer, P. Cherubini, Siegwolf R. T. W., Cotrufo M. F., 2009: Tree rings indicate differentdrought resistance of a native (Abies alba Mil.) and a non-native (Picea abies [L.] Karst.) species cooccurring at a drysite in Southern Italy. Forest Ecology and Management, 257:820-828.

Bernadzki, E., 2008: Jodła pospolita - ekologia, zagrożenia, hodowla. PWRiL, Warszawa, p. 7-9.

Bhuyan, U., Zang, C., Menzel, A., 2017: Different responses of multispecies tree ring growth to various drought indices across Europe. Dendrochronologia, 44:1-8.

Binkley D., Fisher, R. F., 2013: Ecology and Management of Forest Soils. 4th Edn. Chichester:Wiley-Blackwell, $347 \mathrm{p}$.

Biondi, F., Waikul, K., 2004: Dendroclim 2002: AC++ program for statistical calibration of climate signals in tree ring chronologie. Computers \& Geosciences, 30:303-311.

Blaschke, H., 1982: Schadbild und Ätiologie des Tannensterbens: III. Das Vorkommen einer Phytophthora-Fäule an Feinwurzeln der Weißtanne (Abies alba Mill.). European Journal of Forest Pathology, 12:232-238. 
Block, J., 1997: Disposition rheinland-pfälzischer Waldbodensubstrate gegenüber Versauerung. In: Ministerium für Umwelt und Forsten Rheinland-Pfalz: Waldschäden. Boden- und Wasserversauerung durch Luftschadstoffe in Rheinland-Pfalz, Mainz, p. 16-27.

Boettger, T., Haupt, M., Friedrich, M., Waterhouse, J. S., 2014: Reduced climate sensitivity of carbon, oxygen and hydrogen stable isotope ratios in tree-ring celulose of silver fir (Abies alba Mill.) influenced by background $\mathrm{SO}_{2}$ in Franconia (Germany, Central Europe). Environmental Pollution, 185:281-294.

Bolte, A., Ammer, C., Löf, M.,Madsen, P., Nabuurs, G.-J., Schall, P. et al., 2009: Adaptive forest management in central Europe: climate change impacts, strategies and integrative concept. Scandinavian Journal of Forest Research, 24:473-482.

Bolte, A., Hilbrig, L., Grundmann, B., Kampf, F., Brunet, J., Roloff, A., 2010: Climatechange impacts on stand structure and competitive interactions in a southernSwedish spruce-beech forest. European Journal of Forest Research, 129:261-276.

Bonan, G. B., 2008: Forests and climate change: forcings, feedbacks, and the climate benefits of forests. Science, 320:1444-1449.

Bontemps, J. D., Hervé, J. C., Leban, J. M., Dhôte, J. F., 2011: Nitrogen footprint in a long-term observation of forest growth over the twentieth century. Trees Structural and Function, 25:237-251.

Bošela, M., Petráš, R., Sitková,Z., Priwitzer, T., Pajtík, J., Hlavatá, H. et al., 2014: Possible causes of the recent rapid increase in the radial increment of silver fir in the Western Carpathians. Environmental Pollution, 184:211-221.

Bošela, M., Lukac, M., Castagneri, D., Sedmák, R., Biber, P., Carrer, M. et al., 2018: Contrasting effects of environmental change on the radial growth of cooccurring beech and fir trees across Europe. Science of the Total Environment, 615:1460-1469.

Brill, H., Bock, E., Bauch, J., 1981: Über die Bedeutung von Mikroorganismen im Holz von Abies alba Mill. für das Tannensterben. Forstwissenschaftliches Centralblatt, 100:195-206.

Büntgen, U., Tegel, W., Kaplan, J. O., Schaub, M., Hagedorn, F., Bürgi, M. et al., 2014: Placing unprecedented recent fir growth in a European-wide and Holocene-long context. Frontiers in Ecology and the Environment, 12:100-106.

Bunn, A., Mikko, K., 2018: Chronology Building in dplR. CRAN - R Project, 13 p.

Cailleret, M., Davi, H., 2010: Effects of climate on diameter growth of co-occurring Fagus sylvatica and Abies alba along an altitudinal gradient. Trees, 25:265-276.

Carrer, M., Motta, R., Nola, P., 2010: Significant mean and extreme climate sensitivity of Norway spruce and silver fir at mid-elevation mesic sites in the Alps. PLoS One, 7: e50755.

Coumou, D., Rahmstorf, S., 2012: A decade of weather extremes. Nature Climate Change, 2:491-496.
Cramer, H. H., 1984: On the Predisposition to Disorders of Middle European Forests. In: PantzenschutzNachrichten Bayer, 37, p. 97-207.

Cukor, J., Vacek, Z., Linda, R., Vacek, S., Marada, P., Šimůnek, V. et al., 2019a: Effects of bark stripping on timber production and structure of Norway spruce forests in relation to climatic factors. Forests, 10:320.

Cukor, J., Vacek, Z., Linda, R., Sharma, R. P., Vacek, S., 2019b: Afforested farmland vs. forestland: Effects of bark stripping by Cervus elaphus and climate on production potential and structure of Picea abies forests. PloS one, 14:e0221082.

Crookston, N. L., Stage, A. R., 1999: Percent canopy cover and stand structure statistics from the Forest Vegetation Simulator. Gen. Tech. Rep. RMRSGTR-24. Ogden, UT. U.S. Department of Agriculture, Forest Service, Rocky Mountain Research Station, $11 \mathrm{p}$.

Čada, V., Svoboda, M., Janda, P., 2013: Dendrochronological reconstruction of the disturbance history and past development of the mountain Norway spruce in the Bohemian Forest, central Europe. Forest Ecology and Management, 295:59-68.

Čater, M., Diaci, J., 2017: Divergent response of European beech, silver fir and Norway spruce advance regeneration to increased light levels following natural disturbance. Forest Ecology and Management, 399:206-212.

Dănescu, A., Albrecht, A. T., Bauhus, J., 2016: Structural diversity promotes productivity of mixed, unevenaged forests in southwestern Germany. Oecologia, 182:319-333.

Davis, M. B., Shaw, R. G., Etterson, J. R., 2005: Evolutionary responses to a changing climate. Ecology, 86:1704-1714.

De Vries, W., Reinds, G. J., Gundersen, P., Sterba, H., 2006: The impact of nitrogen deposition on carbon sequestration in European forests and forest soils. Global Change Biology, 12:1151-1173.

del Río, M., Schütze, G., Pretzsch, H., 2014: Temporal variation of competition and facilitation in mixed species forests in Central Europe. Plant Biology, 16:166-176.

Di Filippo, A., Biondi, F., Maugeri, M., Schirone, B., Piovesan, G., 2012: Bioclimate andgrowth history affect beech lifespan in the Italian Alps and Apennines. Global Change Biology, 18:960-972.

Diaci, J., 2011: Silver fir decline in mixed old-growth forests in Slovenia: an interaction of air pollution, changing forest matrix and climate. In: Moldoveanu, A. (ed.): Air Pollution - New Developments. InTech, p. 263-274.

Dittmar, C., Zech, W., Elling, W., 2003: Growth variations of common beech (Fagus sylvatica L.) under different climatic and environmental conditions in Europe - a dendroecological study. Forest Ecology and Management, 173:63-78. 
EEA, 2006: European forest types: categories and types for sustainable forest management reporting and policy. EEA Technical Report No 9/2006 (Copenhagen), $114 \mathrm{p}$.

Elling, W., Dittmar, C., Pfaffelmoser, K., Rötzer, T., 2009: Dendroecological assessment of the complex causes of decline and recovery of the growth of silver fir (Abies alba Mill.) in Southern Germany. Forest Ecology and Management, 257:1175-1187.

Elliott, K. J., Miniat, C. F., Pederson, N., Laseter, S. H., 2015: Forest tree growth response to hydroclimate variability in the southern Appalachians. Global Change Biology, 21:4627-4641.

Fabrika, M., Duurský, J., 2005: Stromové rastové simulátory. Zvolen, EFRA, 112 p.

Farjon, A., Filer, D., 2013: An Atlas of the World's Conifers: An Analysis of their Distribution, Biogeography, Diversity and Conservation Status, Brill, 524 p.

Ferretti, M., Innes, J. L., Jalkanen, R., Saurer, M., Schäffer, J., Spiecker, H. et al., 2002: Airpollution and environmental chemistry - what role fortree-ring studies? Dendrochronologia, 20:159-174.

Forrester, D. I., Kohnle, U., Albrecht, A. T., Bauhus, J., 2013: Complementarity in mixed-species stands of Abies alba and Picea abies varies with climate, site quality and stand density. Forest Ecology and Management, 304:233-242.

Forrester, D. I., Albrecht, A. T., 2014: Light absorption and light-use efficiency in mixtures of Abies alba and Picea abies along a productivity gradient. Forest Ecology and Management, 328:94-102.

Frank, D., Reichstein, M., Bahn, M., Thonicke, K., Frank, D., Mahecha, M. D. et al., 2015: Effects of climate extremes on the terrestrial carbon cycle: concepts, processes and potential future impacts. Global Change Biology, 21:2861-2880.

Friedrichs, D. A., Trouet, V., Büntgen, U., Frank, D. C., Esper, J., Neuwirth, B. et al., 2009: Species-specific climate sensitivity of tree growth in Central-West Germany. Trees, 23:729-739.

Fritts, H. C., 1976: Tree Ring and Climate. Academic Press, New York, 576 p.

Füldner, K., 1995: Strukturbeschreibung in Mischbeständen. Forstarchiv, 66:235-606.

Gao, X., Giorgi, F., 2008: Increased aridity in the Mediterranean region under green-house gas forcing estimated from high resolution regional climate projections. Global Planetary Change, 62:195-209.

Gazol, A., Camarero, J. J., Gutierrez, E., Popa, I., AndreuHayles, L., Motta, R. et al., 2015: Distinct effects of climate warming on populations of silver fir (Abies alba) across Europe. Journal of Biogeography, 42:1150-1162.

Gazol, A., Camarero, J. J., Anderegg, W. R. L., VicenteSerrano, S. M., 2016: Impacts ofdroughts on the growth resilience of Northern Hemisphere forests. Global Ecolology and Biogeography, 26:166-176.
Gentilesca, T., Todaro, L., 2008: Crescita radiale e risposte climatiche dell'abete bianco (Abies alba Mill.) in Basilicata.Forest@-Journal of Silviculture and Forest Ecology, 5:47-56.

Godek, M., Sobik, M., Błaś, M., Polkowska, Ž., Owczarek, P., Bokwa, A., 2015: Tree rings as an indicatorof atmospheric pollutant deposition to subalpinespruce forests in the Sudetes (Southern Poland). Atmospheric Research, 151:259-268.

Gömöry, D., Longauer, R., Liepelt, S., Ballian, D., Brus, R., Kraigher, H. et al., 2004: Variation patterns of mitochondrial DNA of Abies alba Mill. in suture zones of postglacial migration in Europe. Acta Societatis Botanicorum Poloniae, 73:203-206.

Gričar, J., Čufar, K., 2008: Seasonal dynamics of phloem and xylem formation in silver fir and Norway spruce as affected by drought. Russian Journal of Plant Physiologist, 55:538-543.

Halaj, J. et al., 1987: Rastové tabulky hlavných drevín ČSSR. Bratislava, Príroda, 361 p.

Hanewinkel, M., Cullmann, D. A., Schelhaas, M.-J., Nabuurs, G.-J., Zimmermann, N. E., 2013: Climate change may cause severe loss in the economic value of European forest land. Nature Climate Change, 3:203-207.

Härdtle, W., Niemeyer, T., Assmann, T., Baiboks, S., Fichtner, A., Friedrich, U. et al., 2013: Long-term trends in tree-ring width and isotope signatures $\left(\delta^{13}\right.$ $\mathrm{C}, \delta^{15} \mathrm{~N}$ ) of Fagus sylvatica L. on soils with contrasting water supply. Ecosystems, 16:1413-1428.

Harrington, C. A., Gould, P. J., St. Clair, J. B., 2010: Modeling the effects of winter environment on dormancy release of Douglas-fir. Forest Ecology and Management, 259:798-808.

Hartmann, H., Adams, H. D., Anderegg, W. R., Jansen, S., Zeppel, M. J., 2015: Research frontiers in droughtinduced tree mortality: crossing scales and disciplines. New Phytologist, 205:965-969.

Hauck, M., Zimmermann, J., Jacob, M., Dulamsuren, C., Bade, C., Ahrends, B. et al., 2012: Rapid recovery of stem increment in Norway spruce at reduced $\mathrm{SO}_{2}$ levels in the Harz Mountains, Germany. Environmental Pollution, 164:132-141.

Hejný, S., Slavík, B. (eds.), 1997: Květena České republiky. 1. díl, Praha, Academia, 557 p.

Hernández, L., Camarero, J. J., Gil-Peregrín, E., Sánchez, M.Á. S., Cañellas, I., Montes, F., 2019: Biotic factors and increasing aridity shape the altitudinal shifts of marginal Pyrenean silver fir populations in Europe. Forest Ecology and Management, 432:558-567.

Huber, M. O., Sterba, H., Bernhard, L., 2014: Site conditions and definition of compositional proportion modify mixture effects in Picea abies-Abies alba stands. Canadian Journal of Forest Research, 44:1281-1291.

Choat, B., Jansen, S., Brodribb, T. J., Cochard, H., Delzon, S., Bhaskar, R. et al., 2012: Global convergence in the vulnerability of forests to drought. Nature, 491:752-755. 
Jaehne, S. C., Dohrenbusch, A., 1997: Ein Verfahren zur Beurteilung der Bestandesdiversität. Forstwissenschaftliches Centralblatt, 116:333-345.

Klein, T., 2014: The variability of stomatal sensitivity to leaf water potential across tree species indicates a continuum between isohydric and anisohydric behaviours. Functional Ecology, 28: 1313-1320.

Knibbe, B., 2007: PAST4: personal analysis system for treering research, Version 4.2. SCIEM, Vienna.

Kogan, F., Adamenko, T., Guo, W., 2013: Global and regional drought dynamics in the climate warming era. Remote Sensing Letters, 4:364-372.

Konôpková, A., Kurjak, D., Kmet', J., Klumpp, R., Longauer, R., Ditmarová, L. et al., 2018: Differences in photochemistry and response to heat stress between silver fir (Abies alba Mill.) provenances. Trees Structure and Function, 32:73-86.

Koprowski, M., 2013: Spatial distribution of introduced Norway spruce growth in lowland Poland: The influence of changing climate and extreme weather events. QuaternaryInternational, 283:139-146.

Korpel', S., Paule, L., Laffers, A., 1982: Genetics and breeding of the silver fir (Abies alba Mill.). Annal Forestry, 9:151-184.

Král, J., Vacek, S., Vacek, Z., Putalová, T., Bulušek, D., Štefančík, I., 2015: Structure, development and health status of spruce forests affected by air pollution in the western Krkonoše Mts. in 1979-2014. Lesnícký časopis - Forestry Journal, 61:175-187.

Králíček, I., Vacek, Z., Vacek, S., Remeš, J., Bulušek, D., Král, J. et al., 2017: Dynamics and structure of mountain autochthonous spruce-beech forests: impact of hilltop phenomenon, air pollutants and climate. Dendrobiology, 77:119-137.

Larsen, J. B., 1986: Das Tannensterben: eine neue Hypothese zur Klärung des Hintergrundes dieser rätselhaften Kompexkrankheit der Weisstanne (Abies alba Mill.). Forstwissenschaftliches Centralblatt, 105:381-396.

Lebourgeois, F., Rathgeber, C. B. K., Ulrich, E., 2010: Sensitivity of French temperate coniferous forests to climate variability and extreme events (Abies alba, Picea abies and Pinus sylvestris). Journal of Growing Science, 21:364-376.

Lenoir, et al., 2009: Differences between tree species seedling and adult altitudinal distribution in mountain forests during the recent warm period (19862006). Ecography, 32:765-777.

Margalef, R., 1958: Information theory in ecology. General Systematics, 3:36-71.

McDowell, N. G., Allen, C. D., 2015: Darcy's law predicts widespread forest mortality under climate warming. Nature Climate Change, 5:669-672.

Metz, J., Annighöfer, P., Schall, P., Zimmermann, J., Kahl, T., Schulze, E.D. et al., 2016: Site-adapted admixed tree species reduce drought susceptibility of mature European beech. Global Change Biology, 22:903-920.
Meunier, C. L., Gundale, M. J., Sanchez, I. S., Liess, A., 2016: Impact of nitrogen deposition on forest and lake food webs in nitrogen-limited environments. Global Change Biology, 22:164-179.

Mina, M., del Río, M., Huber, M. O., Thürig, E., Rohner, B., 2018: The symmetry of competitive interactions in mixed Norway spruce, silver fir and European beech forests. Journal of Growing Science, 29:775-787.

Mrkva, R., 1994: Korovnice kavkazska (Dreyfusianordmannianae Eckstein), obrana proti ní a její podíl na ústupu jedle. Lesnictvi - Forestry, 40:361-370.

Musil, I., Hamerník, J., 2007: Jehličnaté dřeviny. Přehled nahosemenných i výtrusných dřevin, Lesnická dendrologie 1, Praha, Academia, 352 p.

O’Brien, M. J., Leuzinger, S., Philipson, C. D., Tay, J., Hector, A., 2014: Drought survival of tropical tree seedlings enhanced by non-structural carbohydrate levels. Nature Climate Change, 4:710.

Petráš, R., Pajtík, J., 1991: Sústava česko-slovenských objemových tabuliek drevín. Lesnícky časopis, 37:49-56.

Pielou, E. C., 1975: Ecological diversity. New York: Wiley, USA, $165 \mathrm{p}$.

Pretzsch, H., 2006: Wissen nutzbar machen für das Management von Waldökosystemen. Allgemeine Forstzeitschrift/Der Wald, 61:1158-1159.

Pretzsch, H., Schütze, G., Uhl, E., 2013: Resistance of European tree species to drought stress in mixed versus pure forests: evidence of stress release by interspecific facilitation. Plant Biology,15:483-495.

Pretzsch, H., Rötzer, T., Matyssek, R., Grams, T. E. E., Häberle, K. H., Pritsch, K. et al., 2014: Mixed Norway spruce (Picea abies [L.] Karst.) and European beech Fagus sylvatica [L.] stands under drought: from reaction pattern to mechanism. Trees, 28:1305-1321.

Putalová, T., Vacek, Z., Vacek, S., Štefančík, I., Bulušek, D., Král, J., 2019: Tree-ring widths as an indicator of air pollution stress and climate conditions in different Norway spruce forest stands in the Krkonoše Mts. Central European Forestry Journal, 65:21-33.

Reineke, L. H., 1933: Perfecting a stand-density index for even-aged forests. Journal of Agricultural Research, 46:627-638.

Ripullone, F., Borghetti, M., Raddi, S., Vicinelli, E., Baraldi, R., Guerrieri et al., 2009: Physiological and structural changes in response toaltered precipitation regimes in a Mediterranean macchia ecosystem. Trees, 23:823-834.

Rita, A., Gentilesca, T., Ripullone, F., Todaro, L., Borghetti, M., 2014: Differential climate-growth relationships in Abies alba Mill. and Fagus sylvatica L. in Mediterranean mountain forests. Dendrochronologia, 32:220-229.

Rolland, C., Michalet, R., Desplanque, C., Petetin, A., Aimé, S., 1999: Ecological requirements of Abies alba in the French alps derived from dendro-ecological analysis. Journal of Growing Science, 10:297-306. 
Roman, D. T., Novick, K. A., Brzostek, E. R., Dragoni, D., Rahman, F., Phillips, R. P., 2015: The role of isohydric and anisohydric species in determining ecosystem-scale response to severe drought. Oecologia, 179:641.

Rötzer, T., Biber, P., Moser, A., Schäfer, C., Pretzsch, H., 2017a: Stem and root diameter growth of European beech and Norway spruce under extreme drought. Forest Ecology and Management, 406:184-195.

Rötzer, T., Häberle, K. H., Kallenbach, C., Matyssek, R., Pretzsch, H., 2017b: Tree species and size drive water consumption of beech/spruce forests (Fagus sylvatica/Picea abies) - a simulation study highlighting growth under water limitation. Plant Soil, 418:337-356.

Sander, C., Eckstein, D., 2001: Foliation of spruce in the Giant Mts. and its coherence with growth and climate over the last 100 years. Annals of Forest Science, 58:155-164.

Sensuła, B., Wilczyński, S., Opała, M., 2015: Tree Growth and Climate Relationship: Dynamics of Scots Pine (Pinus sylvestris L.) Growing in the Near-Source Region of the Combined Heat and Power Plant During the Development of the Pro-Ecological Strategy in Poland. Water, Air, \& Soil Pollution, 226:220.

Shannon, C. E., 1948: A mathematical theory of communications. Bell System Technical Journal, 27:379_ 423.

Schweingruber, F. H., 1996: Tree Rings and Environment Dendroecology. Swiss Federal Institute for Forest, Snow and Landscape Research, Birmensdorf, $609 \mathrm{p}$.

Sohar, K., Altman, J., Lehečková, E., Doležal, J., 2017: Growth-climate relationships of Himalayan conifers along elevational and latitudinal gradients. International Journal of Climatology, 37:2593-2605.

Swidrak, I., Gruber, A., Oberhuber, W., 2014: Xylem and phloem phenology in co-occurring conifers exposed to drought. Trees, 28:1161-1171.

Šmilauer, P., Lepš, J., 2014: Multivariate analysis of ecological data using CANOCO 5. Cambridge university press, $361 \mathrm{p}$.

Toïgo, M., Vallet, P., Perot, T., Bontemps, J.-D., Piedallu, C., Courbaud, B., 2015: Overyielding in mixed forests decreases with site productivity. Journal of Ecology, 103:502-512.

Ulrich, B., 1981: Eine ökosystemare Hypothese über die Ursachen des Tannensterbens (Abies alba Mill.). Forstwissenschaftliches Centralblatt, 100:228-236.

Úradníček, L., Maděra, P., Kolibáčová, S., Koblížek, J., Šefl, J., 2001: Dřeviny České republiky. Písek, Matice lesnická, 333 p.

Úradníček, L., Madera, P., Tichá, S., Koblížek, J., 2009: Dřeviny České Republiky. Lesnická práce, Kostelec nad Černými lesy, 367 p.

Usbeck, T., Wohlgemuth, T., Dobbertin, M., Pfister, C., Bürgi, A., Rebetez, M., 2010: Increasing storm damage to forests in Switzerland from 1858 to 2007. Agricultural and Forest Meteorology, 150:47-55.
Vacek, S., Hůnová, I., Vacek, Z., Hejcmanová, P., Podrázský, V., Král, J. et al., 2015: Effects of air pollution and climatic factors on Norway spruce forests in the Orlické hory Mts. (Czech Republic), 1979-2014. European Journal of Forest Research, 134:1127-1142.

Vacek, S., Černý, T., Vacek, Z., Podrázský, V., Mikeska, M., Králíček, I., 2017: Long-term changes in vegetation and site conditions in beech and spruce forests of lower mountain ranges of Central Europe. Forest Ecology and Management, 398:75-90.

Vacek, S., Vacek, Z., Kalousková, I., Cukor, J., Bílek, L., Moser, W.K. et al., 2018. Sycamore maple (Acerpseudoplatanus L.) stands on former agricultural land in the Sudetes-evaluation of ecological value and production potential. Dendrobiology, 79:61-76.

Vacek, S., Vacek, Z., Ulbrichová, I., Remeš, J., Podrázský, V., Vach, M. et al., 2019: The Effects of Fertilization on the Health Status, Nutrition and Growth of Norway Spruce Forests with Yellowing Symptoms. Scandinavian Journal of Forest Research, 34:1-49.

Vacek, Z., Vacek, S., Slanař, J., Bílek, L., Bulušek, D., Štefančík, I. et al., 2019: Adaption of Norway spruce and European beech forests under climate change: from resistance to close-to-nature silviculture. Central European Forestry Journal, 65:129-144.

Viet, H. D., Kwak, J. H., Lee, K. S., Lim, S. S., Matsushima, M., Chang, S. X. et al., 2013: Foliar chemistry and tree ring $\delta 13 \mathrm{C}$ of Pinus densiflora in relation to tree growth along a soil $\mathrm{pH}$ gradient. Plant and Soil, 363:101-112.

Vitali, V., Büntgen, U., Bauhus, J., 2017: Silver fir and Douglas fir are more tolerant to extréme droughts than Norway spruce in south-western Germany. Global change biology, 23:5108-5119.

Vitali, V., Büntgen, U., Bauhus, J., 2018: Seasonality matters - The effects of past and projected seasonal climate change on the growth of native and exotic conifer species in Central Europe. Dendrochronologia, 48:1-9.

Wentzel, K. F., 1980: Weissitanne = immissionsempfindlichste einheimische Baumart. Allgemeine Forstzeitschrift, 35:373-374.

Werner, B., Spranger, T. (ed.), 1996: Manual on Methodologies and Criteria for Mapping Critical Levels/Loads and Geographical Areas where they are Exceeded, UN ECE CLRTAP. Berlin, UBA, 204 p.

Wilczyński, S., 2006: The variation of tree-ring widths of Scots pine (Pinus sylvestris L.) affected by air pollution. European Journal of Forest Research, 125:213-219.

Yamaguchi, D. K., 1991: A simple method for crossdating increment cores from living trees. Canadian Journal Forest Research, 21:414-416. 